\title{
Talent Management and Organizational Quality Improvement
}

\author{
llir Rexhepi, PhD Candidate
}

Kosovo Management Institute; ilirexhepi@gmail.com

\section{Dr. Besarta Vladi}

EUT / Department of Management \& Economics; besarta.vladi@uet.edu.al

Doi:10.5901/ajis.2015.v4n3p157

\section{Abstract}

\begin{abstract}
Today's challenges of talent management and organizational quality improvement are very different from the challenges that were facing businesses years ago. On a daily basis, businesses are facing competition to keep a substantial part of the market. Many companies have realized that to achieve this goal, you need to invest more significantly in organizational quality management and human resources. Most managers have now realized that investing in quality management and to their employees development makes the company successful. Management of talent and quality has become a central component of functional and organizational strategic development. Talent and quality undoubtedly should be developed and continuously improved within an organization. "The importance of quality and talent management has been a priority in the life cycle of organizational quality activities and Human Resources (Dhanabhankyam \& Kokilambal, 2014). Good talent and quality management provides a quality assurance and confidence to the organization. By having guaranteed quality and talented employees, the organization creates competitive advantage (Lawler, 2009). Quality and talent management strategies are important to any organization, regardless of how profitable they are. In this context, the question we seek to answer in this paper is: Which are the most successful talent and quality management in various international companies and how much important are these strategies to be implemented in the Albanian and Kosovar companies? Results of this analysis will help us better understand the importance of quality and talent management within an organization and the benefits brought by them to the performance of the organization in the globalization era.
\end{abstract}

Keywords: knowledge economy, quality management, talent management, sustainable development.

\section{Introduction}

Talent management "is the process of recruitment, evaluation, management and maintenance of the most important people in the organization '(Khatri, 2010).

Continuous Quality Improvement (CQI) is a quality management process that encourages all organizational team members to continuously ask the questions, "How are we doing?" and "Can we do it better?" (Edwards, 2008). More specifically, can we do it more efficiently? Can we be more effective? Can we do it faster? Can we do it in a more timely way? Continuous improvement begins with the talent management throughout the above mentioned processes. Talent and organizational quality improvement through training processes have become one of the most essential issues of HR in an organization (Bersin, 2006). The importance of talent management and organizational quality improvement is evident from the way they have evolved within an organization. In the years 1970-1980 there was a group of so called "Personnel Department", which dealt with employment, wages, personal safety and insurance etc. Later in the years 1980-1990 the organizations realized that the role of HR was far more important and transform to the name "Strategic Human Resources" and the role of this group included: the recruitment of the right people, training and development, structure organization, order execution and employee motivation. In this part, the HR department through the organizational quality improvement returned from a business function in a business partner. In recent years we are entering in a new era so called "Talent Management", where human resources through organizational quality improvement are focused on a more complete strategy: in doing things in a more efficient and effective way, in the development of values and credibility within the organization, in adequacy training in relevant and flexible way (Bersin, 2006). 


\subsection{The purpose and objective of this paper}

The main purpose of this paper is to analyze the importance of today's talent management for organizational quality improvement. The specific objective is to study and analyze the managerial strategies of talent management and to recommend them to national businessmans, entrepreneurs and CEOs in Kosovo and Albania, in order to help them in the process of talent management improvement in their organizations.

\subsection{Research question, hypothesis and paper methodology}

The research question we will examine in this paper is: which are the most successful strategies of talent management and organizational quality improvement in various international companies and how much important are these strategies to be implemented in Albanian and Kosovar companies?

The basic hypothesis of this paper is that as best as we manage the talent, we better realize the organizational quality improvement through achieving its long time targeted goals and objectives. In due to the fact that "talent management" is not a concept and technique very well known in the Albanian and Kosovo context, this paper will be based mainly on the discussion of secondary data. In further studies, we pretend to specifically test the applied strategies and actions taken from Albanian and Kosovar companies in terms of organizational quality improvement through talent management.

The first part of the paper is focused on the strategies and practices of talent management and benefits that talent can bring into an organization. In the second part will become a analogy of the results achieved in the first part of the paper to the Albanian and Kosovo context of business, with the aim of awareness of Albanian and Kosovo entrepreneurs towards the nowadays importance of investing in organizational quality improvement through talent management. The relevant conclusions and recommendations will form the concluding part of this paper.

This study is based on secondary data, focused on analytical literature review. We have taken into consideration the newest paper on talent management, published in scholar google.

\section{Talent Management as a Strategic Business Objective}

Today employers are faced with a different market from previous years and it is difficult to keep potential employees with relatively high level of competences. Organizations are faced with a very high competition and it is increasingly difficult to maintain the highest level of activity expansion (Oracle, 2014). Globally, more than half of employers show that employment has increased in relation to last year. "This study shows that it is difficult to find and retain talent within an organization" (Towers Watson, 2014). Today ' employees, more than ever have the opportunity to transfer, move and employed in almost every corner of the world. In this context, the concept of stability in employment is gradually replaced with the concept of employee stability. This is because the talented employees at any time are likely to leave the organization, which represents the multidimensional costs for the organization in question.

PwC's global annual survey of CEOs shows that $63 \%$ of respondents are concerned about the future availability of key skills of their employees. This result makes us understand better the reason why small and medium enterprises increasingly focus on talent management. The ninth annual survey Manspower Group about the lack of talent has shown that $54 \%$ of employers who report a lack of talent, say it has a significant impact on their ability to meet customer needs. However, the frequent movement of talented employees from one organization to another, turns out to be negative due to their not long term commitment to an organization, the level of innovation and creativity in it '(Manpower Group, 2014). On the other hand, the departure of talent from the organization compels the latter to employ less talented people, which brings damage to the performance of the organization and cannot bring it to the desired levels of organizational quality improvement. Many business leaders say that there is a problem in talent management and agree that talent management programs need to be improved in order to maintain the continuous organizational quality improvement. On the other hand, the solution of this problem towards the needs of businesses has been slow. This because such a system (that realizes what human resources management need) is costly to maintain and implement (Oracle Corporation, 2014).

Things are changing in a positive way, starting from the wider business strategies towards the way what talents require to achieve success. Successful companies are focusing on managing talent effectively and efficiently (Oracle, 2014). Talent management requires the integration and communication between existing companies for the key functions of human resources (Bersin, 2006). Also senior executives claim that employees convey the business value. Every business relies on key talents in order to implement its strategies. Talented employees have an added value to business 
customers and shareholders. They are well-trained and knowledgeable not only about their work but they are able to resolve any possible situation that can occur in business. Such skills and knowledge are a major requirement for any organization, because "if the employees do not have the skills to meet the demands of customers, then the organization fails in all terms including organizational quality improvement. If employees understand where they are most beneficial to the organization and managers clearly express what they want from employees, then their collaboration is a reflection of the realization of the goals and objectives of the organization (The Economist Intelligence, 2007).

Businesses benefit when individual employee goals are in line with business goals. In this respect human resources help businesses by ensuring that the goals of both are almost the same and can co- exist. "Managing real talent is a key to being competitive," (Oracle, 2014, p.5). Therefore, more than ever, human resources managers should pay more attention towards the selection of appropriate staff in order to achieve the organizational goals and its process of quality improvement. The mobility of talent creates attraction and simultaneous challenge at the same time.

\section{Talent Management \& HR practices}

Talent management is a continuous and integrated process for the recruitment, training, management, support and compensation of these individuals. Talent management process includes workforce, recruiting, placing talents in the management board, performance management, continuous planning, compensation, critical skills, etc. (Bersin, 2006). Talents in the organization have some common characteristics:

- Talent requires specific and general skills

- Talent requires individual and team skills

- Talent requires assessment \& consciousness

- $\quad$ Talent requires competence, commitment \& willingness (Preeti Khatri, 2010)

Practices of proper talent management are intended to enhance the organizational quality improvement, performance of the organization, workforce and professional development of government employees (Dhanabhankyam \& Kokilambal, 2014). Talent management is related to each phase of the HR activities within the organization.

$\checkmark$ Talent management and workforce - this process creates the workforce, employment plans and employment budget for the following year.

$\checkmark$ Talent management and recruitment - through this process becomes proper appraisal proper for the proper selection of employees.

$\checkmark$ Management of talent and training - this practice has great importance as it provides a way of learning and development of programs for different levels of the organization. Above all, talents are managed through categories and in accordance with the organization's strategic objectives.

$\checkmark$ Talent management and rewards - in this function organizations strive to match the compensation plan in the direct way with management of performance so that the benefits, incentives and rewards are linked with business objectives.

$\checkmark$ Talent management and their inclusion on the management board - the organization must train its workers in order to be more productive and integrated in the company, especially when it comes to their involvement in important organizational quality improvement and decision-making.

$\checkmark$ Talent management and performance management - while using the business plan, the organization establishes processes for management and assessment of employees.

$\checkmark$ Talent management and continuous planning - this function provides HR managers to identify the appropriate candidates for a certain position in the future. Continuous planning should also be in accordance with the business plan in order to understand and meet requirements for key positions (3-5 years).

$\checkmark$ Management of talent and critical skills - analyzes the disadvantages and improves them. In nowadays many organizations are moving towards critical talent management (Bersin, 2006).

Organization should have clear current and future strategies that will follow. They should identify the disadvantages of existing talents and know what other additional talents they need for the future (Wellins, Smith \& Scott).

Chart no. 1 : Use of talent strategies by different industries

\section{Technology \& Talent Management}

Companies continue investing in talent, by sacrificing their productivity. Having talented people in an organization is definitely a great achievement. On the other hand knowing how to manage them is the key to success (Association of 
Municipalities of Albania, 2001). Companies tend to invest in talent more increasingly, because through talent they manage to achieve their goals. The most common forms of investment in talent include:

$\checkmark$ Individual engagement to meet the goals and objectives of the organization

$\checkmark$ Professional development of teams \& individuals

$\checkmark$ Effective performance management

$\checkmark$ Selection of the best talents for promotions

$\checkmark$ Reducing communication challenges

$\checkmark$ Communication in all disciplines \& ages

$\checkmark$ Evaluation of talents for the best ones to join the organization

$\checkmark$ Finding talent from outside the organization

$\checkmark$ Success with contractors (Project Management, 2013)

However, investment with the higher costs in terms of talent management has to do with technological investment. Technological developments are directly related to human resources, and specifically with talent management and quality improvement in the organization. Through the implementation of information technology in the function of the Human Resources department, it is one more reason that makes this more strategic department and gives the opportunity to have a direct impact on business success (Road 2014 ). Recent decades have transformed the HR department in a genuine technological system that ensures talent management, offering a recruitment sophisticated strategy that effectively covers the stages of the employee lifecycle. Technology has helped in managing talent more effectively, has simplified the work of human resources, has changed the way how Human Resources realize the talent management process etc., (Oracle, 2014).

\section{Albanian and Kosovo Business Context and Organizational Talent Management}

As part of the emerging economies, the labor market in Albania and Kosovo still is not in the stage where employees systematically move from one to another company. In contrary, the high level of unemployment is a significant indicator to understand somehow the context of business in the respective countries. What it seems as a concern of many employees is the guarantee for a job and its sustainability in the job market. This probably relates to the high number of graduates each year from different universities on the one hand and the small number of employment possibilities on the other hand. In this situation, the senior organizational managers do not seem to feel enough "pressure" of talents leaving their organization. Consequently, their investment in terms of talent management is relatively low. However, the opening of the labor market in the context of globalization and the free movement of workers, should be seen as a threat by Albanian and Kosovo companies. This for the simple fact that talented employees have more than ever the opportunity to be employed outside the borders of Albania and Kosovo, in various organizations and companies all over the world. For this reason, senior managers in Albania and Kosovo should be aware of the importance of investment in terms of talent management, so that they may see themselves as part of the organizational quality improvement and as part of their long-term plans. Few local and foreign companies operating in Albania and Kosovo, such as Vodafone, IPKO, Kosovo Management Institute and some other business consulting companies, bring the positive spirit of the investment in the talents within the organization through differentiated personal payment, investment in training and further qualification of talented employees, providing the career opportunity, involvement in most important organizational decision making including quality improvement etc. Perhaps this is a good example for Albanian and Kosovo entrepreneurs to follow in order to guarantee their long-term success in the market.

\section{Conclusions}

Nowadays almost every organization is looking for talents that will work longer for them. Employees are aware of their importance as a fundamental asset of any organization and therefore their claims are increasing day by day. Thus, keeping talent within the organization has become more difficult. It is understood that talent management process starts from the interviewing process by seeing if the employee is suitable for the organization and continuous to the division of employees based on their expertise and skills within the organization. With the increase of competition the lack of talents and the effects of globalization through organizational quality improvement will bring greater need for talent management in the right direction within an organization. However, companies are moving in the direction of talent management in a more integrated and systematic way.

If we refer to the Albanian and Kosovo business context, at the first glance it seems that talent management is not 
yet a necessity because employees tend to be long-term as a job and are not for constant movement from one to another company. However, globalization has already established the possibility for employees (including those of the Albanians and Kosovars) to move not only inside their national borders, but in every corner of the globe. This phenomenon, driven also by uncertainty and political instability, it could turn into a serious threatening risk to for businesses in Albania and Kosovo. For this reason, entrepreneurs in these two countries should priorities the contemporary strategies of talent management, in order to continually improve the organization quality and prevent (rather than simply correct) consequences that can be caused by the phenomenon of systematic movement of workers in the future.

\section{References}

Bersin \& Associates, (2010), 'Talent Management: Benchmarks, Treds, \& Best Practices', http://www.hreonline.com/pdfs/TalentMgmt Benchmarks06162010.pdf

Josh Bersin, Principal , (2006), 'Talent Managemnt What is it? Why not?', http://www.bf.umich.edu/docs/KeyReferenceArticles.pdf

Khatri Preeti, (2010), ' Talent Management in HR', http://www.sciedu.ca/journal/index.php/jms/article/viewFile/64/22

Laywer E. (2009), 'Make Human Capital A Source of competitive Advantage, Organizational Dynamics-38(1), 1-7 file:///C:/Users/Floril Downloads/materiali\%204-\%20Manage-A\%20Study\%20on\%20existing\%20talent\%20management\%20practiceK.\%20Kokillambal\%20(3).pdf

Manpower Group (2014) 'The Talent Shortage Continues'

Oracle Corporation, (2014), 'An Innovative Approach to Strategic Talent Management in the Cloud' http://www.oracle.com/us/products/ applications/human-capital-management/talent-management-2315742.pdf

Project Management Institute-Headquarters, (2013), ' The competitive advantage of effective organizational talent management',

http://www.pmi.org/ /media/PDF/Business-Solutions/PMExecutiveSummaryTalentMgmt.ashx

Richards S.Wellins, Audrey B.Smith, Scott Erker,'White Paper' https://www.ddiworld.com/DDIWorld/media/white-papers/ninebest practicetalentmanagement_wp_ddi.pdf

Silk Road Talent Talk, (2014), 'The State of TalentManagement 2014', http://www.nasrecruitment.com/uploads/files/2014-state-of-talentmanagement-101.pdf

Towers watson, (2014), 'Global Talent Management and Rewards Study' file:///C:/Users/Flori/Downloads/materiali\%202-\%202014global-talent-management-and-rewards-study-towers-watson\%20(1).pdf

The Economist Intelligence Unit, (2013), 'Building an integrated talent management strategy' http://www.zanett.com/assets/pdf/wp_ datasheets/Economist-White-Paper-building-an-integrated-talent-management-strategy.pdf

Shoqata e Bashkive të Shqipërisë, (Korrik,2001),'Menaxhimi Modern i Burimeve Njerëzore', Përgatitur nga projekti KOMPAS, Tiranë f-q 7. 
